\title{
Pengetahuan Siswa Tentang Resiko Menikah Dini Melalui Pendekatan Promosi Kesehatan
}

\author{
Samuel M. Simanjuntak, Mikaria Doloksaribu \\ Fakultas IImu Keperawatan, Universitas Advent Indonesia \\ Email: smsimanjuntak@unai.edu
}

\begin{abstract}
Abstrak
Pernikahan dini merupakan silent issue terkait kesehatan dan hak asasi manusia. Jawa Barat merupakan salah satu provinsi di Indonesia dengan insiden pernikahan dini yang tertinggi setelah Kalimantan Tengah. Pendekatan promosi kesehatan yang diberikan sedini mungkin kepada anak remaja usia sekolah diharapkan akan menumbuhkan kesadaran terhadap resiko menikah dini. Metode pelayanan masyarakat yang diterapkan adalah dengan pemberian promosi kesehatan kepada para remaja. Target populasi dalam kegiatan pelayanan masyarakat ini adalah seluruh siswa kelas 2 di SMPN 3 Karyawangi. Kegiatan promosi kesehatan meliputi perkenalan, pengukuran pengetahuan awal tentang resiko menikah dini, pemberian materi dengan metode pengajaran dan audio visual UNICEF, sesi tanya jawab, pengukuran pengetahuan post tentang resiko menikah dini dan sesi penutupan. Instrumen yang digunakan untuk mengkaji pengetahuan adalah kuesioner yang diadopsi dari Ellizabet (2010) dengan 20 butir pertanyaan. Hasil kajian tingkat pengetahuan remaja siswa SMP menunjukkan adanya perbedaan tingkat pengetahuan tentang resiko menikah dini antara sebelum dan sesudah promosi kesehatan. Peningkatan nilai pengetahuan remaja tentang resiko pernikahan dari sebelum promosi kesehatan dengan sesudah adalah $14,11 \%$ dengan $p$ value $\leq 0.000$. Pendekatan promosi kesehatan melalui diskusi dan audio-visual menunjukkan pengaruh yang baik dalam meningkatkan pengetahuan remaja tentang resiko pernikahan dini. Sebagai lembaga pendidikan dasar, SMPN 3 Karyawangi dapat memfasilitasi penyuluhan kesehatan secara berkala dan berkesinambungan sebagai upaya meningkatkan pengetahuan dan kesadaran remaja mengenai resiko menikah dini. Dosen-dosen, mahasiswa perawat dan tenaga kesehatan lainnya diharapkan bersedia menjadi mitra sekolah-sekolah dalam pelaksanaan promosi kesehatan dalam upaya pencegahan kejadian pernikahan dini. Bagi LPPM untuk terus mengadvokasi pengembangan pelayanan masyarakat dengan mengkoordinasi penerapan hasil penelitian pendekatanpendekatan promosi kesehatan dalam pelaksanaan peran universitas sebagai mitra pemerintah mengembangkan derajat kesehatan masyarakat.
\end{abstract}

Kata kunci: Anak usia sekolah, resiko pernikahan dini, promosi kesehatan, pengetahuan

\begin{abstract}
Early marriage is a silent issue related to health and human rights. West Java is one of the provinces in Indonesia with the highest incidence of early marriage after Central Kalimantan. Health promotion given as early as possible to school-age children is expected to foster awareness of the risks of early marriage. The community service approach applied is the provision of health
\end{abstract}


promotion to teenagers. The target population of this community service program is all $2^{\text {nd }}$ year students at SMPN 3 Karyawangi. The activities of health promotion include introductions, measurement of initial knowledge, provision of material for the risk of early marriage with teaching approach and watching movies on the early marriage risks by UNICEF, question and answer sessions, post measurement of knowledge and ending with farewell sessions. The instrument used to assess knowledge is a questionnaire adopted from Ellizabet (2010) with 20 questions. The results show that there is a significant difference in the level of knowledge about the risk of early marriage between before and after health promotion toward junior high school students. The increment of the knowledge about the risk of marriage between before and after health promotion is $14.11 \%$ with $p$ value $=0.000$. Evidently, a health promotion approach through discussion and audio-visual is effective in increasing adolescent knowledge about the risks of early marriage. For the educators of SMP 3 Karyawangi, it is suggested to facilitate health education regularly and continuously to increase the teens knowledge and awareness about the risk of early marriage. For lecturers and nursing students and other health workers to be willing to become partners of schools in the implementation of health promotion in an effort to prevent the occurrence of early marriage. For LPPM to continue advocating the development of community services by coordinating the implementation of the results of researches on health promotion approaches in the implementation of the role of the university as a government partner to improve the health of the society.

Keywords: School-age children, early marital risks, health promotion, knowledge

\section{PENDAHULUAN}

Remaja merupakan tunas awal suatu bangsa untuk menjadi bangsa yang lebih baik, bermartabat dan kuat. Oleh karena itulah, masa depan suatu bangsa terletak di tangan para remaja. Namun fakta menunjukkan bahwa banyak remaja masih terjebak dalam masalah melakukan pernikahan dini. Hasil penelitian United Nations Children's Fund (UNICEF) mencatat bahwa 1 dari 6 anak perempuan di Indonesia menikah sebelum usia 18 tahun. Angkanya 340.000 anak per tahun. Adapun yang di bawah usia 15 tahun mencapai 50.000 anak per tahun. Maka tak heran apabila United National Development Economic and Social Affair (UNDESA), menempatkan Indonesia pada peringkat ke-37 dunia dan peringkat ke-2 se-ASEAN sebagai salah satu negara dengan angka pernikahan usia dini yang tinggi. Mengapa isu pernikahan dini menjadi krusial? Isu pernikahan dini adalah salah satu topik yang menjadi perhatian penting pada kerangka kerjasama Sustainable Development Goals. Pemerintah di seluruh dunia sudah bersepakat menghapus perkawinan anak pada 2030 (UNICEF, 2014).

Dari hasil pendataan Badan Kependudukan dan Keluarga Berencana Nasional terakhir menunjukkan bahwa $46 \%$ atau sekitar 2,5 juta pernikahan yang terjadi setiap tahun di Indonesia dilakukan oleh remaja perempuan dan laki-laki dengan rentang usia diantara 15-19 tahun. Fakta yang diperoleh menunjukkan bahwa insidensi pernikahan dini paling banyak terjadi di wilayah Kalimantan Tengah 52,1\% dari total pernikahan per tahunnya. Kemudian di urutan selanjutnya antara lain adalah daerah Jawa Barat dengan 50,2 \%, Kalimantan Selatan 48,4 persen, Bangka Belitung 47,9 persen, dan Sulawesi Tengah 46,3\% (BKKBN, 2012, 2016). 
Banyaknya faktor yang menjadi penyebab terjadinya pernikahan dini tidak menghentikan dampak buruk yang terjadi akibat pernikahan dini. Dampak buruknya antara lain adalah gangguan pada kesehatan fisik dan mental. Secara fisik remaja dalam usia yang muda belum cukup kuat, tulang pinggulnya masih terlalu kecil sehingga memiliki resiko tinggi gangguan saat proses persalinan. Sebagai contoh kasus adalah yang terjadi di Nanggroe Aceh Darussalam dimana tingginya kematian ibu hamil pada pasangan yang menikah dini (PDIKemenkes, 2014).

Pernikahan dini secara fisiologis memiliki akibat buruk bagi para remaja dimana pada saat hamil dan melahirkan akan sangat mudah menderita anemia. Ketidaksiapan fisik remaja yang melakukan pernikahan dini juga dapat terjadi pada anak yang dilahirkan. Dampak buruk tersebut berupa bayi lahir dengan berat yang rendah. Berat badan lahir rendah ini akan menjadikan bayi tersebut tumbuh menjadi remaja yang tidak sehat, tentunya ini juga akan berpengaruh pada kecerdasan buatan si anak dari segi mental (Manuaba, 2013).

Perempuan yang menikah di bawah usia 20 tahun beresiko terkena kanker leher rahim, karena pada usia remaja sel-sel leher rahim belum tumbuh dengan matang. Apabila terpapar oleh Human Papiloma Virus (HPV) maka pertumbuhan sel akan menyimpang menjadi kanker. Kanker leher rahim menduduki peringkat pertama dari jenis kanker yang menyerang perempuan Indonesia, angka kejadiannya saat ini 23\% diantara kanker lainnya. Masalah kematian dan morbilitas ibu juga dikontribusikan oleh kelompok remaja. Lebih dari seperlima penduduk Indonesia yang berjumlah 206 juta adalah para remaja berusia 10-18 tahun. Data Survei Demografi dan Kesehatan Indonesia mengindikasikan terjadinya peningkatan jumlah wanita muda (di bawah 16 tahun) telah menikah menjadi 15,66\% (BKKBN, 2018). Data Badan Pusat Statistik RI mengidentifikasikan bahwa terdapat sekitar $23 \%$ wanita yang pernah menikah sebelum berusia 18 tahun (2017).

Pengabdian masyarakat dan penelitian ini bertujuan untuk berperan dalam program pemerintah untuk mencerdaskan bangsa dan meningkatkan derajat kesehatan dan kesejahteraan peserta didik melalui memberikan pemahaman yang baik tentang pernikahan dan hakikat keluarga. Pendidikan kesehatan .pencegahan pernikahan dini diharapkan akan membangun pemahaman remaja yang baik tentang resiko pernikahan dini dan akan membangun sikap dan perilaku yang baik tentang pernikahan. Dengan terbangunnya pengetahuan dan sikap yang baik tentang pernikahan dini maka para remaja akan membuat keputusan yang benar pula dalam melanjutkan pendidikan dalam mempersiapkan masa depan yang lebih bernilai bagi diri, keluarga dan masyarakat

\section{BAHAN DAN METODE}

Pelaksanaan pelayanan masyarakat dengan pendekatan promosi kesehatan ini dibagi menjadi tiga fase. Fase pertama tim penyuluh terlebih dahulu melakukan pengkajian tentang masalah kesehatan di masyarakat yang dinilai prioritas. Setelah melakukan penggalian literatur dan masukan dari hasil wawancara dengan guru-guru di sekolah dasar dan sekolah menengah di kecamatan Parongpong, maka tim pelayanan melakukan perencanaan program pelayanan masyarakat dengan menggunakan pendekatan pengajaran dan audio-visual. Pada tahap ini proposal pengabdian masyarakat pun dibuat, menyerahkan surat permohonan izin pelaksanaan dari LPPM dan dekan Fakultas Keperawatan kepada kepala sekolah SMPN 3 Karyawangi. Surat 
tersebut menjelaskan tujuan dari pelayanan promosi kesehatan, manfaatnya bagi siswa/i kelas 2 dan proses pelaksanaannya. Pendekatan promosi kesehatan bertujuan meningkatkan pengetahuan dan kesadaran remaja tentang resiko pernikahan dini untuk menumbuhkan kesadaran yang lebih baik dalam membina pergaulan.

Pada fase kedua bahan ajar tentang pernikahan dini serta materi penyuluhan audio-visual film singkat oleh UNICEF dipilih dan kemudian alur pelaksanaan pun dirancang bersama. Lebih lanjut, penetapan peran pelaksanaan dan pemeriksaan kesiapan alat-alat bantu ajar menjadi awal langkah fase ini. Promosi kesehatan melibatkan target populasi seluruh siswa/i kelas 2 di SMP Negeri 3 Karyawangi, Kecamatan Parongpong, Kabupaten Bandung Barat Tahun Akademik 2017/2018 yang terdiri dari 6 kelas yang berjumlah 150 siswa laki-laki dan perempuan.

Dengan selesainya pelayanan masyarakat melalui promosi kesehatan tentang resiko menikah dini, maka pencatatan data, analisis dan evaluasi data menjadi aktivitas awal dari fase ketiga. Setelah semuanya selesai maka pelaporan pertanggungjawaban pelaksanaan serta proses publikasi pun dilaksanakan.

\section{HASIL}

Berdasarkan hasil analisis yang tertera pada Tabel 1 di bawah terlihat bahwa nilai ratarata pengetahuan siswa-siswi tentang resiko menikah dini sebelum dilakukan penyuluhan adalah $66,89 \%$ yang diinterpretasikan berpengetahuan sedang. Ini berarti bahwa siswa-siswi tersebut belum memiliki pengetahuan yang cukup tentang resiko menikah dini. Hal tersebut dimungkinkan karena kurangnya informasi tentang resiko menikah dini.

Tabel 1. Tingkat Pengetahuan Remaja Sebelum dan Sesudah Penyuluhan

\begin{tabular}{|c|c|c|c|}
\hline No & Soal & $\begin{array}{l}\text { Nilai } \\
\text { Pre-test }\end{array}$ & $\begin{array}{c}\text { Nilai } \\
\text { Post- } \\
\text { test }\end{array}$ \\
\hline 1 & $\begin{array}{l}\text { Kehamilan pada wanita usia muda mempunyai dampak negatif } \\
\text { terhadap kesejahteraan seorang remaja. }\end{array}$ & 93,3 & 100,0 \\
\hline 2 & Pernikahan dini sangat berpengaruh pada kesehatan reproduksi. & 90,0 & 98,0 \\
\hline 3 & $\begin{array}{l}\text { Menurunnya jumlah kematian ibu melahirkan merupakan dampak } \\
\text { dari pernikahan dini. }\end{array}$ & 66,7 & 96,0 \\
\hline 4 & $\begin{array}{l}\text { Pernikahan dini akan menurunkan resiko Penyakit Menular } \\
\text { Seksual (PMS) }\end{array}$ & 62,7 & 92,7 \\
\hline 5 & $\begin{array}{l}\text { Pernikahan dini akan berdampak pada tingkat kesejahteraan } \\
\text { ekonomi keluarga. }\end{array}$ & 70,0 & 92,7 \\
\hline 6 & $\begin{array}{l}\text { Pernikahan dini akan menjauhkan pasangan usia muda untuk } \\
\text { melakukan penyimpangan seksual. }\end{array}$ & 54,7 & 85,3 \\
\hline 7 & $\begin{array}{l}\text { Ketidaksiapan mental pada saat pernikahan dini merupakan faktor } \\
\text { terjadinya stres pada pasangan usia dini. }\end{array}$ & 90,0 & 85,3 \\
\hline 8 & $\begin{array}{l}\text { Pernikahan dini beresiko akan terjadinya penyulit pada saat } \\
\text { melahirkan seperti perdarahan. }\end{array}$ & 90,0 & 80,0 \\
\hline 9 & Pernikahan dini akan berdampak pada gangguan syaraf otak. & 50,0 & 85,3 \\
\hline
\end{tabular}


10 Pernikahan dini akan mengurangi angka aborsi.

11 Ketidak siapan mental dalam menghadapi kehamilan akan

$36,0 \quad 90,0$

berdampak pada janin yang dikandung oleh wanita usia muda.

12 Pernikahan dini sangat baik untuk tumbang (tumbuh kembang)

$87,3 \quad 92,0$ seks remaja.

13 Wanita yang menikah di bawah usia 20 tahun dapat mencegah terkena kanker serviks.

14 Bayi yang lahir hasil pasangan usia dini akan lebih sehat karena wanitanya hamil masih dalam keadaan subur.

15 Dampak pernikahan dini timbul ketika remaja bergaul di masyarakat.

16 Pernikahan dini dapat mengakibatkan remaja kehilangan kesempatan untuk menuntut ilmu sebagai bekal hidup di masa depan.

17 Pernikahan dini akan meringankan beban psikologis karena sudah halal dalam melakukan hubungan intim.

18 Pasangan usia muda yang belum siap menjalankan kehidupan akan dengan mudah mengakhiri hubungan mereka.

19 Pernikahan dini akan berpengaruh bagi kesejahteraan keluarga dan dalam masyarakat.

20 Pernikahan dini akan terasa harmonis kedepannya karena mereka mulai bersama pada usia yang cukup matang.

\begin{tabular}{ll}
73,3 & 90,7 \\
64,7 & 94,0 \\
64,7 & 95,7 \\
80,7 & 99,3 \\
\hline 100,0 & 97,3 \\
& \\
\hline 48,0 & 95,0 \\
84,0 & 98,0 \\
\hline 70,7 & 96,7 \\
42,0 & 96,7 \\
\hline 66,89 & 93,03
\end{tabular}

TOTAL

Berdasarkan hasil analisis data tertera pada Tabel 1 diatas terlihat bahwa skor pengetahuan siswa-siswi SMP Negeri 3 Karyawangi, Kec. Parongpong Kabupaten Bandung Barat tentang resiko menikah dini sesudah diberikan penyuluhan, adalah tergolong berpengetahuan tinggi $(93,03 \%)$. Hal tersebut menunjukkan bahwa penyuluhan yang disampaikan efektif dalam meningkatkan pengetahuan remaja tentang resiko menikah dini. Penyuluhan dilakukan dengan cara menggunakan power point, dan pemutaran film oleh UNICEF yang mengajarkan siswa-siswi untuk mencega menikah di bawah umur agar tidak terjadi pernikahan dini. Diberikan kesempatan kepada siswa-siswi untuk bertanya dan menjawab hal-hal terkait yang membutuhkan penjelasan lebih dalam.

Hasil analisis untuk melihat adakah perbedaan yang signifikan antara pengetahuan remaja tentang resiko pernikahan dini saat sebelum dan setelah promosi kesehatan tertera pada Tabel 2. Indikasinya adalah terdapat perbedaan yang signifikan antara pengetahuan tentang resiko menikah dini saat sebelum dan sesudah penyuluhan kepada siswa-siswi SMP Negeri 3 Karyawangi, Kecamatan Parongpong, Kabupaten Bandung Barat. Menurut Elgar Dale dalam model teorinya Learning Cone (2012) dan Masters (2013) menyatakan bahwa seseorang yang diberikan pendidikan kesehatan menggunakan alat peraga dan pendekatan audio-visual akan semakin banyak informasi yang diterima sehingga memudahkan seseorang untuk memiliki pemahaman dan informasi, dengan demikian pengetahuan subyek akan meningkat. 
Tabel 2. Perbedaan Tingkat Pengetahuan Remaja Antara Sebelum dan Setelah Penyuluhan

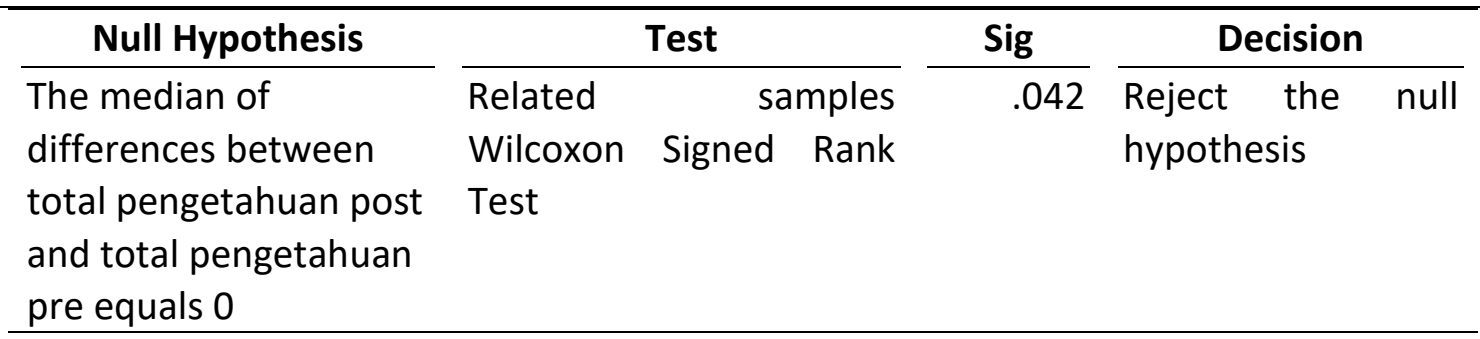

\section{PEMBAHASAN}

Informasi merupakan sebuah pesan dari pengirim kepada penerima pesan, informasi sangat dibutuhkan dalam menciptakan suatu pemikiran, ide, kreatifitas dan isu yang terbaru dalam dunia. Apabila seseorang kurang memiliki informasi yang baru maka orang tersebut akan mengalami keterbelakangan dalam hidupnya, dan kemajuan dalam hidupnya tidak bertumbuh dengan baik (Sujarwo, 2012).

Salah satu upaya pemberian pendidikan kesehatan di sekolah adalah melalui promosi kesehatan. Promosi kesehatan dapat dilakukan dengan menggunakan berbagai metode dan media yang disesuaikan dengan sasaran. Cara efektif dalam pendekatan kelompok adalah dengan metode ceramah dan diskusi. Pada metode ceramah dan diskusi dapat terjadi proses perubahan perilaku kearah yang diharapkan melalui peran aktif sasaran dan saling tukar pengalaman sesama sasaran (Notoatmodjo, 2007).

Menurut Arief S, Sadiman, (dkk) (2010) media merupakan salah satu sarana yang penting dalam penyuluhan kesehatan, media yang biasanya digunakan dalam penyuluhan kesehatan salah satunya media film. Media film adalah layar yang berukuran luas. Sehingga memberikan keleluasaan responden untuk melihat adegan-adegan yang disajikan dalam film. Apalagi dengan kemajuan teknologi film bioskop pada umumnya sudah tiga dimensi sehingga media film lebih menarik, mudah dipahami dan dimengerti karena gambar bergerak seperti nyata.

\section{KESIMPULAN DAN SARAN}

Pengabdian masyarakat dengan pendekatan promosi kesehatan kepada siswa-siswi SMP Negeri 3 Karyawangi Kecamatan Parongpong, Kabupaten Bandung Barat ini menunjukkan bahwa pengetahuan tentang bahaya menikah dini sebelum promosi kesehatan dalam kategori cukup, pengetahuan tentang bahaya menikah dini setelah penyuluhan kesehatan meningkat menjadi kategori tinggi, dan terdapat perbedaan yang signifikan antara pengetahuan tentang bahaya menikah dini saat sebelum dan sesudah promosi kesehatan dengan $p$ value $\leq 0.05$.

Hasil pengabdian masyarakat melalui pendekatan promosi kesehatan ini diharapkan dapat dijadikan referensi atau masukan bagi kegiatan pengabdian masyarakat lainnya untuk dapat menggunakan pendekatan penyuluhan kesehatan berbeda seperti menggunakan leaflet, kelompok kecil, melibatkan orangtua maupun melibatkan pendidikan oleh para pemuka agama yang dilakukan secara berkesinambungan. Dengan pendekatan yang berkesinambungan 
diharapkan menumbuhkan kesadaran generasi muda untuk menempuh pendidikan yang tinggi dan meningkatkan derajat kesehatan dan kesejahteraan masyarakat Indonesia secara umum.

\section{UCAPAN TERIMAKASIH}

Ucapan terimakasih penulis sampaikan kepada LPPM Universitas Advent Indonesia yang telah memberikan arah dan bantuan pendanaan pengabdian masyarakat sehingga kegiatan ini dapat terlaksana dengan baik. Terimakasih kami juga kepada Bapak Kepala Sekolah, guru-guru terhormat dan Bagian Kesiswaan SMPN 3 Karyawangi, Kecamatan Parongpong Kabupaten Bandung Barat yang telah memberikan izin dan banyak membantu terlaksananya promosi kesehatan. Terimakasih kepada Biro Kemahasiswaan serta Dekan Fakultas Keperawatan Universitas Advent Indonesia dan Komisi Etik Penelitian Kesehatan yang telah memberikan dukungan melalui perizinan yang selama ini kami terima. Kami Pun mengucapkan terimakasih kepada seluruh mahasiswa dalam perhimpunan BEM UNAI yang secara sukarela mendukung berlangsungnya pelayanan masyarakat ini.

\section{DAFTAR PUSTAKA}

Arief S, Sadiman, (dkk). 2010. Media Pendidikan. Jakarta: Raja Grafindo Persada

Badan Kependudukan dan Keluarga Berencana Nasional. (2018). Survei Demografi dan Kesehatan Indonesia 2017: Kesehatan Reproduksi Remaja. Jakarta: Badan Kependudukan dan Keluarga Berencana Nasional.

Badan Pusat Satistik. (2017). Perkawinan Usia Anak di Indonesia. Jakarta: BPS.

BKKBN, 2012. Kajian pernikahan dini pada beberapa provinsi di Indonesia: Dampak Over population, akar masalah dan peran kelembagaan di daerah. (Online). (Diperoleh 29 September 2017). Format/Ukuran: PDF/2530 Kb. Dapat diunduh dari: http://www.bkkbn.go.id/hasil\%20pernikahan\%20usia\%20dini\%20BKKBN\%

BKKBN, 2016. Laporan Kinerja Instansi Pemerintah Tahun 2015: Badan Kependudukan dan Keluarga Berencana Nasional. (Online). Diperoleh 15 September 2017 dari https://www.bkkbn.go.id/po-content/uploads/LAKIP BKKBN 2016.pdf.

Dale E., 1969. Audiovisual methods in teaching. 3rd ed. New York: Holt, Reinhart \& Winston.

Depkes RI., 2012. Profil Kesehatan Republik Indonesia Tahun 2012. (Online). (Diperoleh 21 November 2016). http://www.depkes.go.id.

Manuaba, IGB. 2007. Pengantar Kuliah Obstetri. Jakarta : EGC.

Masters K., 2013. Edgar Dale's Pyramid of Learning In medical education: A literature review, Sultanate of Oman. Medical Teacher, No.35: e1584-e1593.

Notoadmodjo. S. (2007). Promosi Kesehatan dan Ilmu Perilaku. Jakarta: Rineka Cipta

Pusat Data dan Informasi Kementerian Kesehatan Republik Indonesia, 2014. Mother's day: Situasi kesehatan ibu.

Sujarwo, R., 2012. Faktor Yang Mempengaruhi Pengetahuan Rendah. [Online]. URK:http://gununglaban.wordpress.com/2012/02/30/faktor-yang-yang-mempengaruhipengetahuan-rendah/[15 September 2017] 
UNICEF, 2013. Ending child marriage: progress and prospect. [Online]. Diperoleh 15 September 2017 dari https://www.unicef.org/media/files/Child Marriage Report 717 LR..pdf. 